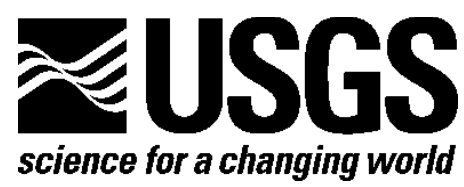

\title{
Geologic Map of the Julian 7.5' Quadrangle, San Diego County, California
}

By Victoria R. Todd

Open-File Report 94-16

U.S. Department of the Interior

U.S. Geological Survey 


\section{U.S. Department of the Interior \\ SALLY JEWELL, Secretary}

\section{U.S. Geological Survey \\ Suzette M. Kimball, Acting Director}

U.S. Geological Survey, Reston, Virginia: 2015

For more information on the USGS-the Federal source for science about the Earth, its natural and living resources, natural hazards, and the environment-visit http://www.usgs.gov/ or call 1-888-ASK-USGS (1-888-275-8747).

For an overview of USGS information products, including maps, imagery, and publications, visit $h t t p: / / w w w . u s g s . g o v / p u b p r o d /$.

Any use of trade, firm, or product names is for descriptive purposes only and does not imply endorsement by the U.S. Government.

Although this information product, for the most part, is in the public domain, it also may contain copyrighted materials as noted in the text. Permission to reproduce copyrighted items must be secured from the copyright owner.

Suggested citation:

Todd, V.R., 2015, Geologic map of the Julian 7.5' quadrangle, San Diego County, California: U.S. Geological Survey Open-File Report 94-16, 18 p., 1 sheet, scale 1:24,000, http://dx.doi.org/10.3133/ofr9416

ISSN 0196-1497 


\section{Contents}

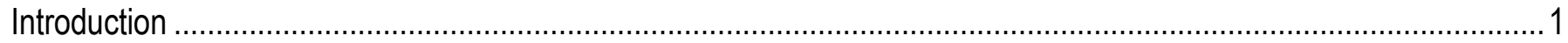

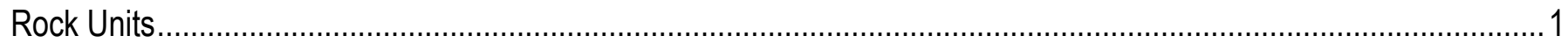

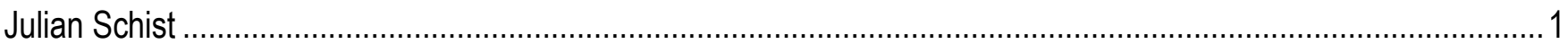

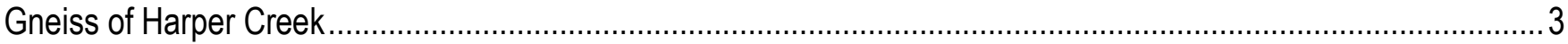

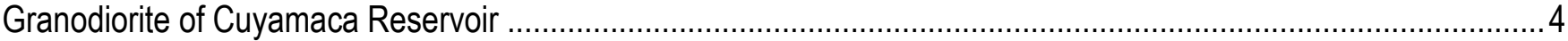

Cuyamaca Gabbro

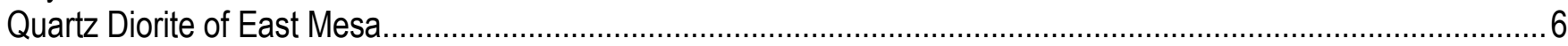

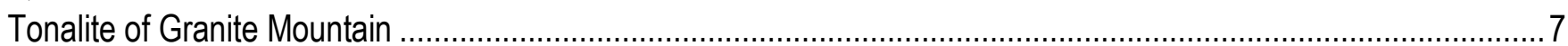

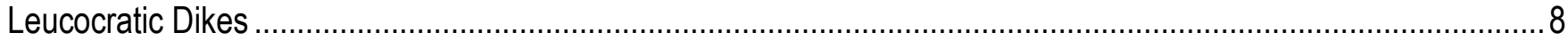

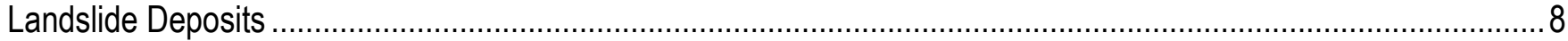

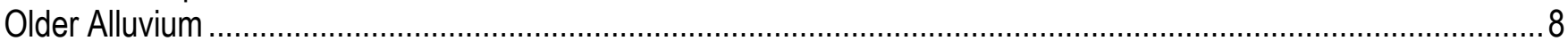

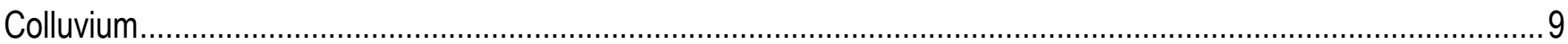

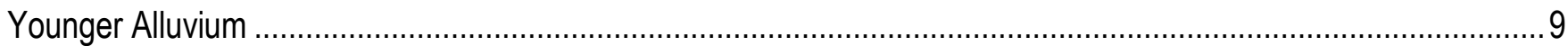

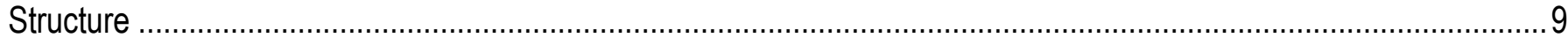

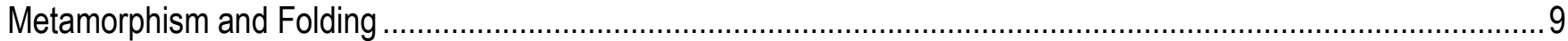

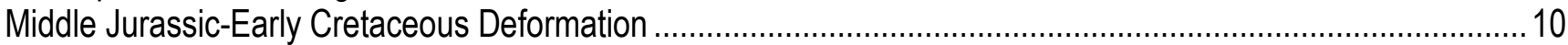

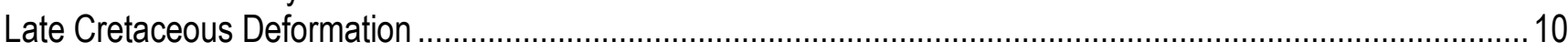

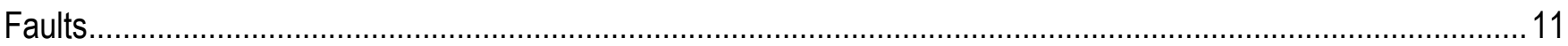

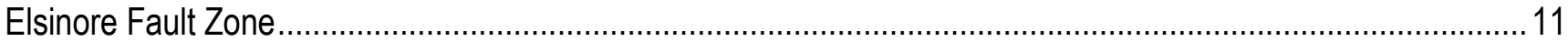

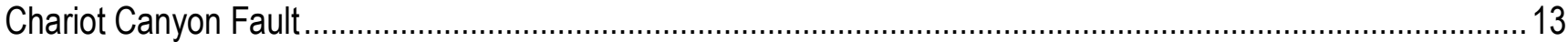

San Felipe Hills Fault Zone ........................................................................................................ 15

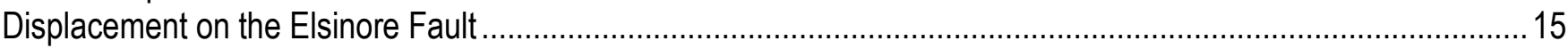

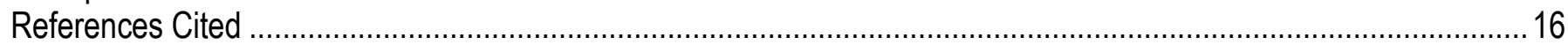

\section{Figure}

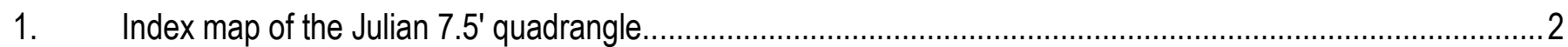

\section{Map Sheet}

1. Geologic map of the Julian $7.5^{\prime}$ quadrangle, San Diego County, California 



\title{
Geologic Map of the Julian 7.5' Quadrangle, San Diego County, California
}

\author{
By Victoria R. Todd
}

\section{Introduction}

The Julian 7.5' quadrangle lies within the Jurassic-Cretaceous Peninsular Ranges batholith of southern California and Baja California. Figure 1 shows the location of the Julian and surrounding 7.5' quadrangles as well as geographic locations mentioned in the text. Four granitic plutonic units and one gabbroic unit, most comprising a number of individual plutons, have been mapped in the Julian quadrangle and informal names have been assigned. The formal name Cuyamaca Gabbro (Everhart, 1951) has been retained. In addition to these plutonic units, metasedimentary and minor metavolcanic rocks occur in steeply dipping tabular bodies, or screens, within and between plutons.

Jurassic plutons in the Julian quadrangle underwent synkinematic metamorphism with the result that plutonic contacts and foliation are concordant with those in the surrounding metamorphosed country rocks. Foliation in Jurassic plutons consists of the planar orientation of recrystallized mineral grains and aggregates; deformation textures include augen gneiss, mylonitic gneiss, and mylonite. Structural studies indicate that a significant part of this deformation took place in the Cretaceous (Bracchi and others, 1993; Thomson and Girty, 1994), and, therefore, the regional foliation in this part of the batholith clearly postdates intrusion of many Cretaceous plutons. Todd and others (1988) and Thomson and Girty (1994) identified deformed rocks in the Julian quadrangle as part of the Early Cretaceous Cuyamaca-Laguna Mountains shear zone (fig. 1).

\section{Rock Units}

\section{Julian Schist}

Prebatholithic rocks in the Julian quadrangle are present within and between plutons as screens and inclusions in a wide range of sizes. The largest screen crosses the quadrangle from southeast to northwest underlying the town of Julian. The metamorphic rocks in the Julian area were first mentioned by Fairbanks (1893) and later described by Merrill (1914), who gave them the name "Julian group." Hudson (1922) presented a detailed description of the rocks, which he called the Julian Schist Series. In a study of the Julian mining district, Donnelly (1934) introduced the name Julian Schist.

The Julian Schist consists of interlayered, intergradational quartzo-feldspathic micaceous semischistose rocks; pelitic schist and paragneiss; calc-silicate-bearing feldspathic metaquartzite; and quartz-rich schists whose protoliths were deposited by turbidity currents on submarine fans (Germinario, 1993). Minor but ubiquitous rocks include small-pebble metaconglomerate; metatuff; white-weathering feldspathic metaquartzite and metaquartzite-pebble conglomerate; and amphibolite and mafic schists. Rare marble olistostromes and talc schists are also present. Local gradation of amphibolite into finegrained metagabbro, together with textures that suggest penecontemporaneous alteration of mafic flows 


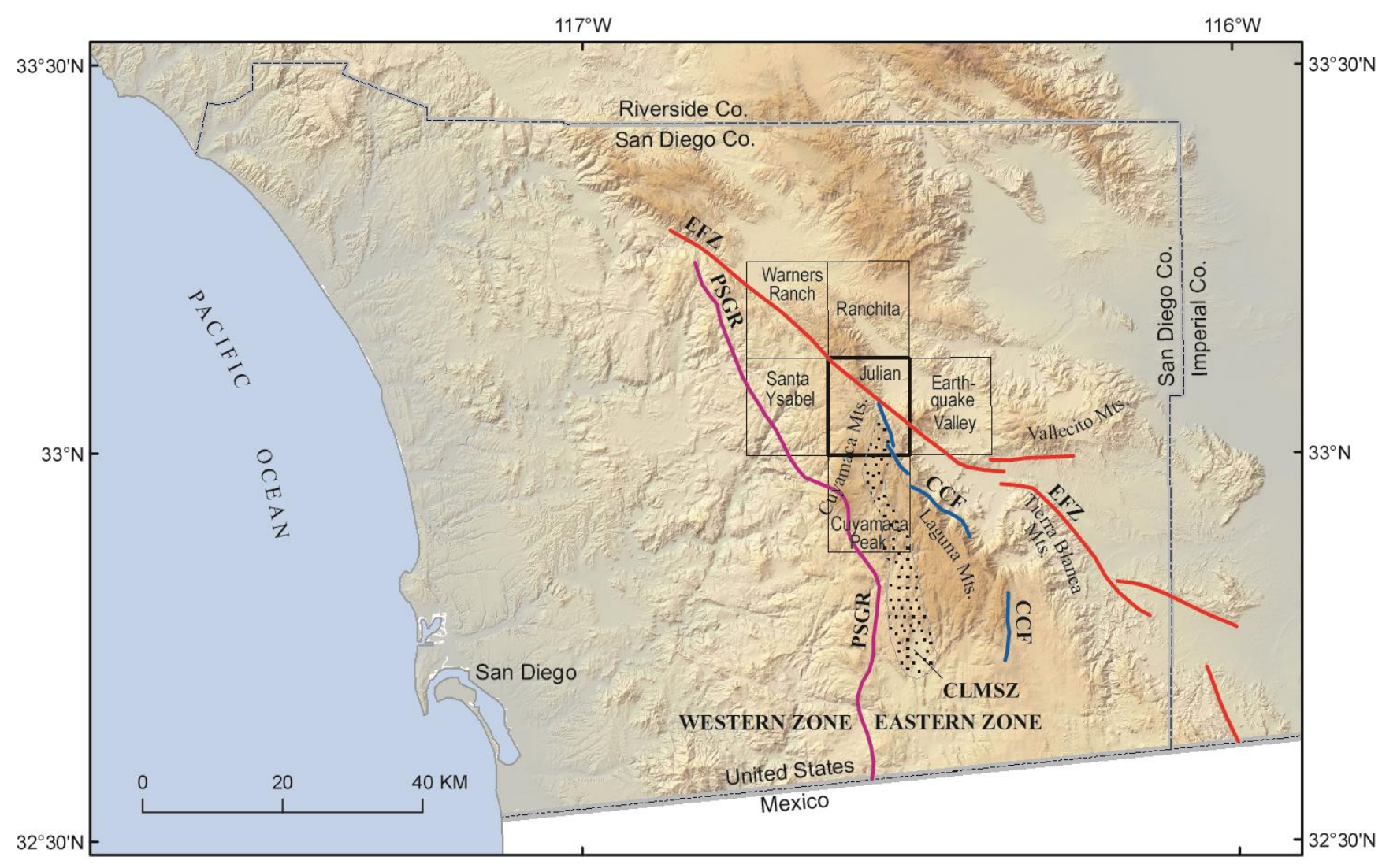

Figure 1. Index map of the Julian 7.5' quadrangle. Map shows western and eastern zones of the Peninsular Ranges batholith, separated by a pseudogravity gradient (PSGR). The pseudogravity gradient represents the mathematical transformation of a steep gradient in magnetic anomalies that extends for at least $800 \mathrm{~km}$ along the axis of the batholith, dividing it into a dense, magnetic western zone and a less dense, relatively non-magnetic eastern zone. Also shown are the Cuyamaca-Laguna Mountains shear zone (CLMSZ; dotted pattern) and the Chariot Canyon Fault (CCF). The Elsinore Fault Zone (EFZ) is shown schematically. Surrounding the Julian quadrangle are five quadrangles: Cuyamaca Peak, Earthquake Valley, Ranchita, Warners Ranch, and Santa Ysabel. 
by sea water, indicate that the amphibolite is largely meta-igneous in origin, as suggested by Donnelly (1934). Intercalation of mafic and metasedimentary layers and a lack of cross-cutting relations further suggest that the mafic rocks originated as flows, tuffs, and shallow sills deposited intermittently on submarine fans. A geochemical study by Foster (1994) confirmed that Julian Schist metabasalts are of MORB affinity.

In the large screen which constitutes the type locality, the Julian Schist is fine-grained and compositional layers are thin, with the exception of locally massive beds of calcsilicate-bearing feldspathic metaquartzite, the latter as much as $4 \mathrm{~m}$ thick. Much of the compositional layering in the unit is the result of isoclinal folding and transposition of folded sedimentary bedding during metamorphism. Sedimentary textures and structures are preserved locally, however, most probably in fold limbs. The protolith of the Julian Schist is considered to have been a fine-grained, thin-bedded marine flysch sequence. Turbidite structures such as graded beds, debris flow deposits, and Bouma sequences (Germinario, 1982) indicate deposition on a submarine fan complex in deep waters off the continental margin. Much of the abundant quartz and feldspar sand was derived from late Proterozoic crust of the North American craton (Bushee and others, 1963). Penecontemporaneous deposition of mafic volcanic rocks indicates nearby volcanic arc activity.

The age of the protolith of the Julian Schist is uncertain. An ammonite imprint in quartzite float was identified as "without much doubt Triassic" (Hudson, 1922, p. 190), but this fossil was later lost. Rubidium-strontium studies of detrital zircons suggest a Triassic-Jurassic depositional age (Gastil and others, 1988), which accords with known or suspected ages of similar prebatholithic rocks to the north in Riverside County and to the south in Baja California (Gastil and Miller, 1984; Todd and others, 1988). The Julian Schist is no younger than Middle Jurassic, because it was intruded by plutons that yield Middle Jurassic zircon ages (discussed below).

\section{Gneiss of Harper Creek}

The gneiss of Harper Creek (Todd, 1977a) typically forms narrow plutons as much as $20 \mathrm{~km}$ long and $6 \mathrm{~km}$ wide. The easternmost plutons are partly mantled by anatectic migmatites consisting of pelitic schist, Harper Creek-type orthogneiss, and paragneiss. Fresh Harper Creek rocks are medium- to dark-gray in color, rich in quartz and mica, and weather to distinctive reddish- and yellowish-brown hues due to oxidation of accessory and trace iron-bearing sulfide minerals. Grain size ranges from fine to coarse; the coarse-grained rocks contain muscovite grains as much as $4 \mathrm{~mm}$ across. Granodiorite is slightly more abundant than tonalite, and monzogranite is a minor phase (Streckeisen, 1973). Roughly half of the samples contain muscovite and (or) sillimanite (mostly fibrolite) and cordierite; garnet was observed in a few samples. A sample from a Harper Creek outcrop in the Mount Laguna 7.5' quadrangle contains cordierite, garnet, andalusite, and sillimanite (G.H. Girty, oral commun., 1991).

The Harper Creek unit is characterized by abundant, uniformly distributed inclusions in a range of sizes and compositions. Largest are raft-like inclusions from $10 \mathrm{~cm}$ to several meters long composed of refractory Julian Schist metasedimentary rock types with lesser fine-grained amphibolite. The unit also contains lenticular biotitic aggregates measuring several centimeters long and from 0.5 to $3 \mathrm{~mm}$ thick, whose length and degree of flattening are greatest in the easternmost plutons. Field studies indicate that these aggregates are relics of larger, partly assimilated pelitic schist inclusions. All of the above inclusions impart a gneissic texture to the rocks; mylonitic gneiss and schist occur near the walls of Harper Creek plutons. The mylonitic rocks contain thin $(\leq 1 \mathrm{~cm}$ long) stringers and flattened segregations of white quartz oriented parallel to foliation. Commonly, mineral foliation and gneissic layering are observed to be parallel to the axial planes of outcrop-scale isoclinal folds.

Stained slabs and thin sections show that granodiorite of the Harper Creek unit is made up chiefly of (in order of decreasing abundance) plagioclase, quartz, biotite, and K-feldspar, set in a finegrained matrix of recrystallized quartz, feldspar, and mica. In most samples, at least a few grains of 
plagioclase and cordierite exhibit relict igneous textures such as subhedral shapes, whereas plagioclase shows patchy euhedral oscillatory zoning and synneusis aggregates (Shaw and others, 2003). Accessory minerals in the Harper Creek unit include graphite, ilmenite, zircon, tourmaline, sillimanite (mostly fibrous habit), cordierite, garnet, and andalusite. Zircon is present as clear euhedral prisms (magmatic grains) and also as subhedral, broken, or rounded pale-tan to yellowish grains (detrital grains). Many grains consist of broken or rounded pale-tan to yellowish cores and euhedral to irregular clear overgrowths.

Contact zones between the gneiss of Harper Creek and metasedimentary screens commonly are marked by interlayering over as much as several tens of meters; migmatite occurs along some contacts. The abundant inclusions of calc-silicate-bearing quartzite, pelitic schist, and amphibolite in contact zones were apparently the most refractory Julian Schist lithologies. Some inclusions comprise remnants of isoclinal fold hinges intruded and transected by granodiorite. These relations, together with close chemical similarities between the two units, suggest that the quartzofeldspathic graywacke component of the Julian Schist melted at depth to form granodiorite and tonalite magma into which the more refractory rocks were entrained. Uranium-lead isotopic age data for Harper Creek plutons in San Diego County indicate a Middle Jurassic (170-160 Ma) age for the main intrusive episode (Shaw and others, 2003), with at least one pluton yielding Late Jurassic ages (Leeson and others, 1989; Thomson and Girty, 1994).

\section{Granodiorite of Cuyamaca Reservoir}

The granodiorite of Cuyamaca Reservoir (Todd, 1977a) forms steep-walled, elongate plutons as much as $20 \mathrm{~km}$ long and $5 \mathrm{~km}$ wide and can also occur as lensoid bodies up to $1 \mathrm{~km}$ long within Harper Creek plutons. The Cuyamaca Reservoir unit consists of subequal biotite granodiorite and hypersthenebiotite tonalite; many samples have borderline compositions, and both granodiorite and tonalite can contain pyroxene \pm actinolitic amphibole \pm scarce hornblende. Plutons of the unit underlie low hills and broad meadows whose outcrops have a distinctive orange-tan weathered color due to oxidation of accessory and trace iron-bearing sulfide minerals. Plutons that border large metasedimentary screens (the latter as much as $2 \mathrm{~km}$ wide) contain marginal mylonitic gneiss with refractory metasedimentary inclusions. In some places, assimilation/contamination reactions between metasedimentary wallrocks and granodiorite in marginal zones produced rocks that closely resemble the gneiss of Harper Creek. Isoclinal folds whose axial planes parallel regional foliation are seen locally in Cuyamaca Reservoir plutons.

Rocks of the Cuyamaca Reservoir unit are fine- to medium-grained and light- to dark-gray on fresh surfaces depending upon color index (C.I.), which ranges from $\sim 16$ to 30. Next to gabbro plutons and mafic dikes, Cuyamaca Reservoir rocks contain fine-grained mafic inclusions, have higher color index, and appear to have assimilated mafic rock. Contaminated Cuyamaca Reservoir tonalite grades along strike into rocks that are more characteristic of the unit.

Granodiorite and tonalite of the Cuyamaca Reservoir unit are made up chiefly of (in approximate order of abundance) plagioclase, subequal quartz and biotite, and K-feldspar and, as stated above, may contain hypersthene \pm actinolitic amphibole \pm hornblende. The average plagioclase composition of the unit ranges from sodic to calcic andesine; some normally zoned grains have cores as calcic as sodic labradorite. Plagioclase in the Cuyamaca Reservoir unit has been modified by strain and recrystallization but shows relict igneous textures such as planar crystal faces against quartz and off-center patches of euhedral oscillatory zoning. Both granodiorite and tonalite of the unit may contain pale green to colorless actinolitic amphibole in a variety of habits: (1) strained prismatic grains partly recrystallized to granoblastic aggregates; (2) sieved prophyroblasts; (3) anhedral grains rimming pyroxene; (4) rare relics and (or) subhedral grains of strongly colored brown or olive-green hornblende; and (5) folia consisting of fine-grained biotite, sphene, ilmenite, chlorite, and epidote. Hypersthene, locally rimmed by 
clinopyroxene, is present chiefly in tonalite as skeletal grains rimmed and replaced by biotite and (or) actinolitic amphibole. Accessory minerals include sphene, ilmenite, apatite, zircon, and allanite.

Contacts between the Cuyamaca Reservoir and Harper Creek units are commonly gradational and, in some places, the rocks are interlayered in zones ranging in width from a few meters to several tens of meters. Near the head of Banner Canyon, Cuyamaca Reservoir and Harper Creek rocks are separated by a gradational zone from 0.5 to $1 \mathrm{~km}$ in width. In other places, the contact is sharp, and the Cuyamaca Reservoir unit may be either leucocratic and coarse-grained, almost pegmatitic, or finegrained against the Harper Creek unit, suggesting that Cuyamaca Reservoir magma intruded Harper Creek rocks. Partial melting or remobilization of Cuyamaca Reservoir rocks by intrusion of Early Cretaceous magmas within the Cuyamaca-Laguna Mountains shear zone locally produced pseudosynplutonic contacts that suggest overlapping intrusive ages. However, recent $\mathrm{U}-\mathrm{Pb}$ zircon dating of three Cuyamaca Reservoir plutons yielded Middle Jurassic ages (170-160 Ma; Shaw and others, 2003).

\section{Cuyamaca Gabbro}

The name Cuyamaca Gabbro, which was applied by Everhart (1951) to large mafic plutons in the Cuyamaca Mountains, has been used for similar mafic plutons throughout southern San Diego County (Todd, 2004). Plutons consisting of troctolite, anorthositic gabbro, gabbronorite, olivine gabbro, hornblende gabbro, and diorite display variable contact relations with adjacent granitic plutons. Granitic intrusions in gabbro typically form concentric sheetlike bodies whose contacts suggest mingling of mafic and granitic magmas (Todd and Shaw, 1979). Thin sections of fine-grained, porphyritic gabbro in contact with such granitic plutons show hypabyssal igneous textures modified by recrystallization. Marginal gabbro grades outward to zones of intrusion breccia consisting of blobs of fine-grained porphyritic gabbro in a matrix of contaminated granitic rock, locally with orbicular gabbro. The intrusion breccia zones grade to the margins of adjacent tonalite plutons that contain abundant large, fine-grained gabbroic dikes and inclusions. In a few places, contacts between gabbro and granitic plutons are sharp and granitic plutons send dikes into gabbro or carry angular gabbro inclusions occurring in boxworks arrangement, suggesting penetration of granitic magma along fractures.

The Cuyamaca Gabbro appears to have crystallized and recrystallized while undergoing strain. Virtually all the gabbro is foliated and, in most cases, primary compositional (cumulate) layering is parallel or near-parallel to the foliation produced by recrystallized mineral aggregates. Locally, a second crosscutting foliation has been superposed on this fabric. In marginal parts of large gabbro plutons and in small bodies, foliation is concordant with regional foliation. Foliation is more complex in the interior parts of the larger plutons, where it may parallel regional foliation or show discordant (swirling?) patterns.

North Peak in the southwest quarter of the Julian quadrangle is underlain by the northernmost gabbro body of a north-elongate gabbroic-granitic complex in the Cuyamaca Mountains (Todd, 1977a). The North Peak "pluton" interfingers with the granodiorite of Cuyamaca Reservoir and the Julian Schist along its northern margin and with the quartz diorite of East Mesa on the southwest. In the Cuyamaca Peak 7.5' quadrangle to the south, gabbro of the Cuyamaca Mountains complex is concentrically intersheeted with the Early Cretaceous monzogranite of Chiquito Peak and to a lesser extent with the granodiorite of Cuyamaca Reservoir; gabbro and monzogranite exhibit mingling textures (Todd and others, 2003). In one locality on Middle Peak, Cuyamaca Reservoir granodiorite appears notably finegrained over about $1 \mathrm{~m}$ next to gabbro. In the Julian quadrangle, mafic dikes that appear to be related to the North Peak gabbro body intruded the Cuyamaca Reservoir unit mobilizing and (or) incipiently melting thin films of granitic melt along dike margins.

Donnelly (1934) and Creasey (1946) considered the northern part of the North Peak gabbro body to form several "salients" that either deformed the surrounding Julian Schist and granodiorite of Cuyamaca Reservoir by forceful intrusion or intruded pre-existing folds in these two units. The present 
study indicates that these salients are lenticular or sheet-like bodies of gabbro that intruded the Julian Schist and Cuyamaca Reservoir units in large part concordantly with foliation and internal contacts, thus defining an arcuate sheeted structure that was later broken and repeated by faulting. In detail, gabbro crosscuts structures in these two units. This intrusive pattern could have resulted from intrusion of mafic magma into already intersheeted or interfolded granodiorite of Cuyamaca Reservoir and Julian Schist, or from contemporaneous mafic and felsic intrusions into Julian Schist. Isotopic ages of gabbro plutons in San Diego County are Early Cretaceous (Todd and others, 2003) but this does not rule out the possibility of Jurassic gabbroic intrusion. A Jurassic gabbro pluton is known from Baja California (D.L.

Kimbrough, written commun., 2009).

The northern part of the North Peak gabbro body was mapped by Creasey (1946) as part of an investigation of strategic nickel, copper, and cobalt resources. He found that compositions ranged from gabbro and norite to peridodite and pyroxenite with gradational contacts; lamprophyre dikes cut all of these rock types. Creasey subdivided the gabbro into four map units on the basis of modal percentages of plagioclase feldspar and ferromagnesian minerals. Sulfide minerals in these rocks are pyrhhotite, pentlandite, violarite $\left(\mathrm{NiS}_{2}\right)$, pyrite, and chalcopyrite. The mineralized zone in the Friday Nickel Mine was described as an irregular body striking about N. $75^{\circ}$ E. and dipping steeply northward. According to Creasey, the mineralized zone formed by replacement of gabbro along fractures on the north side of a Julian Schist inclusion.

Nishimori's (1976) study of the North Peak and Guatay Mountain gabbro plutons focused mainly on the petrogenesis of the Cuyamaca Gabbro. He described compositions ranging from peridodite, through olivine gabbro, gabbro, and amphibole gabbro, to norite, with an average composition of anorthositic gabbro. Most lithologies contain hornblende, ranging from microscopic grains to scattered grains from $0.5 \mathrm{~cm}$ to $\sim 3 \mathrm{~cm}$ long, to trains of larger grains that define nearly continuous hornblendic layers. Cumulate textures in the gabbro were overprinted by protoclastic textures. Based upon his study, Nishimori interpreted the Peninsular Ranges gabbro plutons as fractionally crystallized residua of hydrous high-alumina basalt-basaltic andesite magmas crystallized at crustal depths; in other words, the gabbro plutons most likely represent the roots of andesitic volcanoes. Late amphibolite (lamprophyre) dikes probably represent residual liquids derived by late-stage crystallization of intercumulus liquids. From the high anorthite content of plagioclase feldspar (An90-100), relatively low forsterite $(\mathrm{Mg})$ content of olivine, and calcium-rich clinopyroxene, Nishimori inferred high water pressures in the parental magma.

\section{Quartz Diorite of East Mesa}

The quartz diorite of East Mesa (Todd, 1977a) is intersheeted with the Cuyamaca Gabbro in the southwestern corner of the Julian quadrangle. These outcrops are continuous with a series of small lenticular bodies of quartz diorite and tonalite that are interlayered with gabbro, the granodiorite of Cuyamaca Reservoir, the monzogranite of Chiquito Peak, and the Julian Schist along the western margin of the large gabbroic-granitic complex in the Cuyamaca Peak 7.5' quadrangle to the south (fig. 1). Regionally, the quartz diorite of East Mesa consists of heterogeneous quartz diorite, tonalite, diorite, and granodiorite with lesser monzodiorite and gabbro, typically comprising small plutons and dike swarms that were emplaced into a ductile shear zone (the Cuyamaca-Laguna Mountains shear zone) in the central part of the batholith. East Mesa plutons are strongly foliated, especially near their margins, locally consisting of mylonitic gneiss and mylonite. The East Mesa unit has two textural facies: a darkgray to black, fine- to medium-grained, near-porphyritic facies that carries mafic and metasedimentary inclusions and a lighter-colored, medium-grained facies that carries abundant mafic inclusions. Plutons of the East Mesa unit generally include both textural types in lenticular bodies and mixed zones oriented parallel to regional foliation; locally, the fine-grained facies intrudes the coarser grained facies. 
The dominant East Mesa rock type in the Julian quadrangle is strongly foliated, platy to slabbyjointed (roughly parallel to foliation), fine-grained (quenched?) quartz diorite that is heterogeneous in grain size, mafic mineral content, and presence or absence of mafic inclusions. Heterogeneity increases toward contacts with gabbro, suggesting that the East Mesa magma underwent reaction with, or is petrogenetically related to, the gabbro.

Color index of the quartz diorite of East Mesa over the study area ranges from 23 to 52, decreasing as modal quartz increases. Pale-brown to green hornblende is either the dominant mafic mineral or is about equal in abundance to reddish-brown (reduced) biotite. Rocks whose hornblende crystals enclose pyroxene cores (hypersthene rimmed by clinopyroxene) grade into coarse-grained hypersthene tonalite and quartz gabbro in the center of some East Mesa-type plutons. Relict igneous plagioclase grains (labradorite to andesine) contain oscillatory zoning with strongly calcic cores.

The quartz diorite of East Mesa intrudes, and elsewhere in the study area, may grade to the Cuyamaca Gabbro. South of the Julian quadrangle, the East Mesa unit sends dikes into, and has finegrained (quenched?) margins against, both the Jurassic granodiorite of Cuyamaca Reservoir and the Cretaceous monzogranite of Chiquito Peak. Along the strike of these contacts, plutons of both ages appear to back-intrude the East Mesa rocks (synplutonic and (or) pseudo-synplutonic contacts). This apparent reversal of age relations may be explained by recent U-Pb zircon dating of two East Mesa plutons at $170 \mathrm{Ma}$ and $117 \mathrm{Ma}$ (Shaw and others, 2003). The fine grain size and intense deformation of most East Mesa-type plutons suggest that they crystallized from magma that was emplaced into a ductile shear zone.

\section{Tonalite of Granite Mountain}

The tonalite of Granite Mountain was named informally for exposures at and near Granite Mountain in the Julian and Earthquake Valley 7.5' quadrangles (Todd, 1979). The unit is part of a Cretaceous intrusive sequence in the eastern zone of the batholith that is generally 5 to 15 Ma younger than western-zone plutons. In the Julian quadrangle, the tonalite of Granite Mountain crops out in two main areas comprising (1) rocks on the western flank of Granite Mountain and (2) those on and near Chariot Mountain. Both localities are part of the large pluton that underlies Granite Mountain and extends into the surrounding quadrangles. On the west flank of Granite Mountain and on Chariot Mountain, the tonalite of Granite Mountain intruded the Julian Schist in lit-par-lit fashion; these exposures and the more extensive ones on Granite Mountain to the east appear to represent a series of large sills that expanded during continuing intrusion, eventually cross-cutting and engulfing the metasedimentary layers (M. Grove, oral commun., 1990). Two smaller Granite Mountain-type plutons and numerous related dikes intruded the gneiss of Harper Creek on and near Volcan Mountain. A small outcrop of the Granite Mountain unit at the central-northern boundary of the Julian quadrangle suggests that part of San Felipe Valley is also underlain by this tonalite unit.

The most common rock types of the Granite Mountain unit in the eastern zone of the batholith are medium- to-coarse-grained, white- and grayish-white-weathering hornblende-biotite tonalite and granodiorite containing euhedral to subhedral plagioclase and hornblende grains. The average C.I. of the unit is 21 , due chiefly to subhedral biotite and blocky hornblende prisms up to $2 \mathrm{~cm}$ long; hypersthene cores in hornblende are present in some samples. A few rocks contain pale tannish-green actinolite as sieved or skeletal grains intergrown with hornblende, biotite, and chlorite. Locally, tonalite carries mafic inclusions. Rarely, outcrops show scattered, 5-cm glassy poikilitic K-feldspar grains. Accessory minerals of the tonalite of Granite Mountain include ilmenite, zircon, apatite, allanite, sphene, and garnet. Foliation in Granite Mountain plutons reflects magmatic flow of subhedral hornblende grains and mafic aggregates, but in areas where the rocks are deformed and recrystallized, their texture is mylonitic; here, foliation is subparallel to that in the adjacent older plutonic units and the Julian Schist. 
In a study of tonalitic rocks that crop out east and west of the Elsinore Fault in the vicinity of Chariot Mountain, Lampe (1988) described three gradational zones, from west to east (inward toward the core of the pluton centered at Granite Mountain): biotite-hornblende tonalite with mafic inclusions (Lampe's hornblende-biotite facies), hornblende-biotite tonalite (large-biotite facies), and biotite granodiorite-tonalite (small-biotite facies). On the basis of her study, Lampe concluded that tonalitic rocks on both sides of the fault belong to a single pluton.

The Granite Mountain-type pluton in the Volcan Mountain area, as mapped in this study, consists of idiomorphic to subidiomorphic biotite-hornblende tonalite and hornblende-biotite tonalite with large pseudo-hexagonal biotite grains (Lampe's large-biotite facies). Marginal parts of the pluton and the numerous dikes that are associated with it (many too small to be depicted at the map scale) are more heterogeneous. Small pods and dikes of coeval gabbro and diorite form part of the pluton. On Volcan Mountain, the tonalite of Granite Mountain occurs as dikes in, and carries inclusions of, the granodiorite of Cuyamaca Reservoir and the gneiss of Harper Creek. A sample of the tonalite of Granite

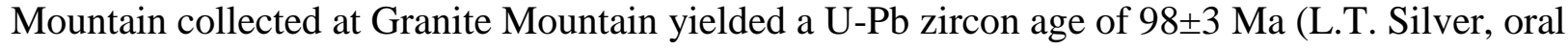
commun., 1979).

\section{Leucocratic Dikes}

Dikes consisting of pegmatite, alaskite, aplite, and leucogranite cut the Harper Creek unit and the Julian Schist. The proximity of most dikes to plutons of the Granite Mountain unit suggests that they are late differentiates of the tonalite of Granite Mountain.

\section{Landslide Deposits}

Landslides occur commonly on the flanks of the large gabbro plutons that typically underlie high peaks in San Diego County. These landslides, which consist almost exclusively of gabbroic clasts, are considered to be Quaternary in age. A road cut though a large deposit on the northeast slope of North Peak exposes several superposed, varicolored layers, each consisting of poorly sorted, chaotic gabbroic materials. The presence of distinct layers in this deposit suggests multiple episodes of sliding. A second possible slide or slump on the northern slope of North Peak is bounded at the top by a lineament, possibly fault-related. Small deposits on the east slope of North Peak obscure contacts between the Cuyamaca Gabbro, the Julian Schist, and the granodiorite of Cuyamaca Reservoir.

Landslides or slumps related to movements on the Elsinore Fault may be present in Banner Canyon on the southern flank of Volcan Mountain. The topography of the steep eastern wall of the canyon suggests that one or more large slumps may be related to a fault (or faults) whose trace lies above the prominent bench that marks the most recent fault activity (see also Weber, 1963). Incipient slumping just below, and parallel to, the crest of Volcan Mountain is suggested by aligned, narrow, vegetation-free slip(?) surfaces. At the base of the east wall, a slide, slump, or thrust(?) consists of brecciated Harper Creek gneiss that overlies coarse alluvial gravels in a nearly flat contact marked by several meters of gouge. The origin of this structure is discussed below, in the section on faults.

\section{Older Alluvium}

The most extensive surficial deposits in the Julian quadrangle are coalescing alluvial fans in San Felipe Valley that overlap the flanks of Volcan and Granite Mountains and the San Felipe Hills. These deposits consist of (1) reddish-brown, poorly indurated, crudely bedded, moderately rounded and sorted sands with cobble and boulder interbeds and (2) fanglomerate; all clast lithologies in these deposits match the bedrock units in the surrounding ranges. Holocene channels have incised the fanheads to depths of at least $12 \mathrm{~m}$. The degree of dissection of the older alluvium in San Felipe Valley is similar to 
that of deposits in Mason and Vallecito Valleys to the south, deposits that are tentatively correlated with the late Pleistocene to Holocene(?) Mesa Conglomerate (Woodard, 1974; Todd, 1978).

In several places in the Julian quadrangle, the older alluvium has distinctive characteristics that have led to subdivision of the unit. On the southeast flank of Volcan Mountain, older alluvium is divided into two partly gradational subunits: unit Qoa $_{1}$ consists of relatively light-colored coarse material near the mountain front, while unit $\mathrm{Qoa}_{2}$ consists of finer-textured, darker material that forms young fans at slightly lower elevations. Qoa 2 grades to extensive younger alluvial deposits in San Felipe Valley. Both $\mathrm{Qoa}_{1}$ and $\mathrm{Qoa}_{2}$ are incised by narrow modern channels. The age of coarse alluvial gravels in Banner Canyon (unit $\mathrm{Qoa}_{3}$ ) that underlie a landslide or thrust consisting of brecciated gneiss of Harper Creek (mentioned above) is unknown, but presumed to be Quaternary. These gravels consist of clasts of the Harper Creek unit and leucocratic dike rocks probably related to the tonalite of Granite Mountainlithologies that constitute the major bedrock exposures on Volcan Mountain. They are at least $10 \mathrm{~m}$ thick where cut by present-day Banner Creek. These gravels are better sorted and rounded and have more laterally continuous beds than those in the modern creek bed. Coarse, poorly sorted alluvium consisting mainly of huge boulders of the Granite Mountain unit $\left(\right.$ Qoa $\left._{4}\right)$ is present at the southeast end of Rodriguez Canyon.

A small deposit of older alluvium consisting of poorly rounded metasedimentary pebbles, cobbles, and sand occurs at an elevation of 4,150 ft in the town of Julian. This deposit displays crude, roughly horizontal bedding and forms low hillocks overlying the Julian Schist, in contrast with Holocene alluvium, which lies in valley bottoms. It is dissected by Holocene streams and is probably Quaternary in age. A road cut though the south end of the deposit exposes a small fault.

\section{Colluvium}

Colluvium consists of slopewash and talus lying on, and at the base of, relatively steep slopes. Locally, these deposits grade into younger alluvium. On the northwest flank of Granite Mountain, colluvial deposits appear to be reworked remnants of the uplifted and dissected alluvial fan and, on higher slopes, they grade into small landslide or rockfall deposits. The age of colluvium is considered to be Holocene.

\section{Younger Alluvium}

The most extensive deposits of younger alluvium in the quadrangle are sand, silt, and gravel in the channels of San Felipe and lower Banner Creeks. Lesser deposits are present in the valley of Santa Ysabel Creek and in Banner and Rodriguez Canyons. Narrow modern stream valleys and meadow lowlands in the Cuyamaca Mountains and Julian Mesa contain relatively thin deposits of sand, silt, and gravel. The age of all these deposits is considered Holocene.

\section{Structure}

\section{Metamorphism and Folding}

The rocks of the Julian area most likely underwent several episodes of high-temperature synkinematic metamorphism, three of which were associated with major intrusive pulses. Jurassic and Cretaceous plutons of the Cuyamaca-Laguna Mountains shear zone are characterized by steep foliation (S1) and steeply plunging folds and lineation (Todd and Shaw, 1979; Todd and others, 1988). Intrusion of the Late Cretaceous tonalite of Granite Mountain was accompanied by recumbent isoclinal folding of S1 and followed by pervasive folding on shallow-plunging axes (Grove, 1987). Grove and others (2003) reported a late Cretaceous structural-metamorphic boundary (the present-day Chariot Canyon Fault) that coincides with the courses of Oriflamme, Chariot, and Banner(?) Canyons and separates two regions of 
differing metamorphic grade and structure. On the east side, protomylonitic tonalite of Granite Mountain and upper amphibolite facies, and migmatitic Julian Schist are folded on shallow-plunging axes, while on the west side, Julian Schist of lower amphibolite facies and Jurassic and Cretaceous plutons are folded on steeply plunging axes.

\section{Middle Jurassic-Early Cretaceous Deformation}

The earliest deformation affected the sedimentary protolith of the Julian Schist prior to, or in association with, intrusion of Middle Jurassic Harper Creek and Cuyamaca Reservoir plutons. Donnelly (1934) interpreted the large metasedimentary screen of the Julian quadrangle as the eastern limb of a northwest-plunging anticline that was intruded by the granodiorite of Cuyamaca Reservoir. Other metasedimentary screens in southern San Diego County have been interpreted as northwest-plunging antiformal structures (Berggreen and Walawender, 1977; Detterman, 1984). As reported in Grove and others (2003), the Julian Schist contains a peak-grade thermal contact aureole surrounding a Cuyamaca Reservoir pluton.

At outcrop scale, Harper Creek and Cuyamaca Reservoir plutons in the Julian quadrangle contain isoclinally folded inclusions of refractory Julian Schist lithologies, chiefly calc-silicate-bearing metaquartzite and amphibolite. The inclusions are crescent-shaped on outcrop surfaces, and appear to be hinges of folds that were intruded and disrupted by granodiorite. In a few places, granodiorite has been folded together with these inclusions and, as mentioned above, the Harper Creek and Cuyamaca Reservoir rocks are themselves isoclinally folded. The axial planes of all of these folds are parallel to a regional foliation that typically consists of northwest-trending, steeply east-dipping mineral foliation and contacts (S1).

Early Cretaceous plutons intruded the cores of large folds involving the Julian Schist and the Harper Creek and Cuyamaca Reservoir units in at least two places in southern San Diego County. The steeply inclined northwest-trending fabric of Harper Creek and Cuyamaca Reservoir plutons is also present in adjacent Early Cretaceous plutons of the Cuyamaca-Laguna Mountains shear zone, suggesting that this fabric partly formed, or was reoriented, during and (or) after Early Cretaceous intrusion. Deformation structures in Middle Jurassic plutons thus apparently resulted from a long period of fabric development in a stress field that maintained the same overall northwest orientation, that is, roughly parallel to the continental margin.

\section{Late Cretaceous Deformation}

Intrusion of the tonalite of Granite Mountain at about $98 \pm 3$ Ma marked a significant change in the regional stress pattern. In the Julian quadrangle, tonalite intruded the Julian Schist in a series of tabular bodies, the largest of which, as described above, expanded to crosscut and mostly engulf metasedimentary layers. Grove (1987) studied structural relations between the Granite Mountain unit and the Julian Schist in the Earthquake Valley 7.5' quadrangle. As reported in Grove and others (2003), their study was expanded to include thermobarometry of the Julian Schist in the southeastern part of the Julian quadrangle, where Grove recognized an abrupt $1.5 \mathrm{~kb} / 100{ }^{\circ} \mathrm{C}$ pressure-temperature gradient that coincides with the present courses of Oriflamme, Chariot, and Banner(?) Canyons (along the Chariot Canyon Fault). West of this gradient, the Julian Schist is relatively fine-grained, sedimentary structures are preserved, $\mathrm{S} 1$ is the dominant fabric element, and folds that formed during peak-grade metamorphism (metapelitic rocks contain andalusite and sillimanite) plunge steeply. Intrusion of the tonalite of Granite Mountain, mainly to the east of this gradient, was accompanied in the Julian Schist by the development of migmatitic veining and obliteration of sedimentary structures; the peak-grade metapelitic assemblage has sillimanite only, and S1 has undergone polyphase folding. At the same time, the tonalite of Granite Mountain was penetratively deformed to mylonitic gneiss, and anatectic migmatites developed in the Julian Schist throughout the eastern region. Grove interpreted the 
metamorphic gradient as a west-directed, deep-seated thrust with $\sim 5 \mathrm{~km}$ structural relief. The continuation of this thrust to the north is suggested by the higher metamorphic grade of both the Julian Schist and the Harper Creek unit on Volcan Mountain as compared with the same rocks west of Banner Canyon.

Intrusion of the areally intensive tonalite of La Posta southeast of the Julian quadrangle (Todd, 1977b) at 95 Ma produced a widespread retrograde metamorphic overprint in metamorphic and plutonic rocks on both sides of the Chariot Canyon Fault. Deformation that accompanied and followed emplacement of the La Posta unit at lower temperatures than those of Grove's "syn-migmatitic deformation" produced tight north-northwest-trending, shallowly plunging folds that range in size from outcrop scale to those with wavelengths on the order of 5 to $10 \mathrm{~km}$. The largest of these folds in the Julian quadrangle is an anticline located in the structural block between the Elsinore and Chariot Canyon Faults (Chariot Mountain). In this fold, the Julian Schist dips northward beneath the tonalite of Granite Mountain, which itself contains northward-dipping screens of the Julian Schist, a geometry that indicates a gentle north-northwest plunge of the anticlinal axis. Tonalite outcrops on Granite Mountain in the Earthquake Valley 7.5' quadrangle are part of a gently plunging syncline-anticline pair (Grove, 1987; M. Grove, oral commun., 1992) that was probably contiguous with the Chariot Mountain anticline and offset from it by Neogene faulting. Scattered shallow-plunging folds and lineation west of the Chariot Canyon fault probably formed at about the same time.

\section{Faults}

Three major fault zones and a number of subsidiary faults are present in the Julian quadrangle: (1) the Elsinore Fault, which has strong topographic expression in Banner Canyon, Ranchito Valley, and Rodriguez Canyon; (2) a prominent fault zone that bounds the southwest flank of the San Felipe Hills in the extreme northeastern part of the quadrangle; and (3) the Chariot Canyon Fault, which is a splay of the Elsinore Fault. Subsidiary faults include a zone of north-northwest-trending faults that extends from Ranchito Valley on the south to the eastern flank of Volcan Mountain. The Elsinore Fault continues southeastward to join the frontal fault zones of the Vallecito, Laguna, and Tierra Blanca Mountains, while the north-northwest faults on the east side of Volcan Mountain may continue southward into Chariot Canyon. The Chariot Canyon Fault strikes southeastward into the Oriflamme Canyon Fault and disappears to the south in the Laguna Mountains block where its trace may be obscured by late Cenozoic normal faults.

\section{Elsinore Fault Zone}

The Elsinore Fault Zone is narrow and linear north of the Julian quadrangle (Kennedy, 1977), but south of the quadrangle it gives way to a broad zone of extension in which individual faults have relatively small right-lateral displacements (Todd, 1978; Hoggatt, 1979). In the Julian quadrangle, the trace of the Elsinore Fault is marked from north to south by the northwest courses of Santa Ysabel and Banner Creeks, Ranchito Valley, and Rodriguez Canyon.

In the valley of Santa Ysabel Creek, the Elsinore Fault truncates a pluton composed of the tonalite of Granite Mountain that intrudes the gneiss of Harper Creek and granodiorite of Cuyamaca Reservoir on Volcan Mountain. On the southwest side of the fault, these Jurassic units and the Julian Schist are intruded by tabular dikes of the Granite Mountain unit (few shown on map). The valley itself is asymmetrical: Volcan Mountain on the northeast rises to about 1,700 m, while Kanaka Flat on the southwest is part of a deeply weathered, gently rolling erosion surface at $\sim 1,250 \mathrm{~m}$, informally called the Julian Mesa in this report. In the narrow, upper part of the valley of Santa Ysabel Creek, the fault is well marked by aligned benches and vegetation stripes in bedrock at the base of Volcan Mountain, but it is covered by alluvium in the broader lower valley near Volcan Road. Immediately west of the Julian quadrangle, near its junction with the Santa Ysabel and Warners Ranch 7.5' quadrangles, the fault may 
have offset a north-northwest-trending contact between the Harper Creek and Cuyamaca Reservoir units by $\sim 1 \mathrm{~km}$ in a right-lateral sense.

Near the intersection of Volcan Road and the road to Cedar Glen camp, the Elsinore Fault bends south-southeast around the base of Volcan Mountain and approaches the head of Banner Canyon. This segment of the fault is marked by a lineament on aerial photographs that gives way to a series of aligned benches near the base of the mountain. A small gabbro body on the southwest side of the fault has been truncated and juxtaposed against the tonalite of Granite Mountain, which intrudes the Harper Creek gneiss on the northeast side of the fault. A Harper Creek road cut in Volcan Road, which follows a linear gully eroded along the fault, exposes one or more $1+\mathrm{m}$, earthy cataclastic zones subparallel to foliation in the Harper Creek unit. Small drainages emanating from Volcan Mountain may show consistent rightlateral bending, and water is seeping in several places from a scarp-like bank located about $100 \mathrm{~m}$ northeast of the main fault trace.

Banner Creek drops in elevation $\sim 800 \mathrm{~m}$ from the head of Banner Canyon to its foot near the settlement of Banner where the creek makes a right-angle northeast bend and enters San Felipe Valley. Banner Canyon is strikingly asymmetrical, with a steep northeast wall and a moderately sloping, more dissected southwest wall. At the head of the canyon, the Elsinore Fault is marked by near-vertical, vegetation-free, highly fractured rock faces located immediately above a series of aligned benches in the northeast wall. Springs and a significant breccia-gouge zone are present near the break-in-slope. South of this segment, the upper $1 \mathrm{~km}$ of the canyon is narrow and heavily vegetated, but a vegetation lineament, aligned benches, and a break in slope line up with fault features at the head of the canyon. A series of subdued bench- or slump-like features higher in the northeast wall of the canyon probably mark the trace of an older break. A poorly exposed contact between the granodiorite of Cuyamaca Reservoir and bouldery older alluvium with locally derived clasts $\left(\mathrm{Qoa}_{3}\right)$ in the bottom of the canyon may mark the location of another break. This feature lines up with apparent truncation of contacts between the Harper Creek and Cuyamaca Reservoir units near the head of the canyon.

In the central part of the northeast wall of Banner Canyon, the Elsinore Fault has traditionally been identified as a prominent bench lying about $80 \mathrm{~m}$ above the creek that lines up with fault features in the upper part of the canyon. Tributary drainages expose breccia-gouge zones and springs at the break in slope between this bench and the steep upper wall of Volcan Mountain. This bench coincides approximately with the upper part of a thick (tens of meters) band of brecciated Harper Creek rocks that overlies undeformed, horizontally stratified, bouldery older alluvium $\left(\mathrm{Qoa}_{3}\right)$ with a sharp contact. This contact, which is exposed for about $1 \mathrm{~km}$, dips gently east and is marked by $\sim 4 \mathrm{~m}$ of white-weathering gouge in brecciated gneiss of Harper Creek. The white-weathering gouge contains thinner zones of bluish-black gouge. The underlying alluvium, locally $\geq 10 \mathrm{~m}$ thick, consists of 0.5 - to $1-\mathrm{m}$, subrounded cobbles and boulders in a sandy matrix containing fine-grained grayish-white layers. Its color and texture contrast with the yellow-weathering angular breccia fragments above the gouge zone. The presence of landslides in Banner Canyon has been suggested previously (Weber, 1963), but this reference appears to have been to a large slump block(?) in the northern part of the canyon. The degree of deformation in the upper plate of the 1-km-long low-angle structure described above seems too great to be explained as a simple landslide. It has the characteristics of the Tertiary and Quaternary gravity slides or detachments that occur widely in eastern California and is similar in size and direction of dip to other low-angle slides of crystalline rocks over sedimentary rocks exposed by high-angle faulting in the southern part of the Elsinore Fault Zone (Todd, 1977b; 1978). In contrast, alluvial gravels on the eastern flank of Volcan Mountain overlie bedrock in a depositional relation. Volcan Mountain may have been thrust westward, in effect closing Banner Canyon and overriding Quaternary alluvium. Regardless of the origin of this feature, the overriding of Quaternary gravels by bedrock probably occurred prior to the most recent episode of high-angle faulting in Banner Canyon: the low-angle structure appears to have been cut by the prominent northwest-trending high-angle fault in the northeast wall of Banner Canyon, 
and, in detail, is offset slightly by minor high-angle cross faults. It may owe its exposure to uplift of Volcan Mountain.

The central bench described above is continuous with two or more vegetation stripes and an indistinct bench, or benches, in the lower part of Banner Canyon. Right-lateral deflection of tributary drainages and the presence of two coarse alluvial cones whose apices expose possible scarps, each several meters high, indicate youthful activity on this segment of the fault. A series of vegetation-free slip(?) surfaces near the western crest of Volcan Mountain may represent incipient slumps.

Immediately southeast of State Highway 78, the Elsinore Fault occupies a narrow northwesttrending valley where it separates tonalite of Granite Mountain containing screens of the Julian Schist in lit-par-lit arrangement on the southwest from gneiss of Harper Creek on the northeast. Screens in the tonalite trend northeast in contrast to predominantly northwest foliation in the Harper Creek unit. In the small valley to the southeast, where the Ranchito mine is located (informally called Ranchito Valley in this report), a large and complex breccia-gouge zone in the Harper Creek unit is exposed at the base of the east wall a short distance northwest of the mine in, and near, the old mine trail. This zone exposes a number of individual fault planes and gouge zones measuring from centimeters to a meter or more, zones that thicken, thin, and anastomose along strike and are oriented parallel to foliation in the Harper Creek unit. The largest of these faults trends N. $31^{\circ} \mathrm{W}$. and dips $50^{\circ}$ to $58^{\circ} \mathrm{NE}$. Other faults in the zone dip gently to the northeast; another strikes N. $78^{\circ}$ E., dips steeply southeast, and bears subhorizontal slickensides. Vegetation lineaments on the slope above the mine trend northwest; many are marked by 30-cm to 1-m zones of black cataclasite.

Several northwest-striking gouge zones in the tonalite of Granite Mountain mark the continuation of the Elsinore Fault between Ranchito Valley and Rodriguez Canyon. The fault is covered by alluvium in Rodriguez Canyon, but its continuation is indicated by the juxtaposition of generally east-northeast-striking foliation and screens in the Granite Mountain unit on Chariot Mountain against generally north-northeast-striking trends in the same rock units on Granite Mountain on the east side of the fault. A major zone of breccia gouge ( 4 to $6 \mathrm{~m}$ wide) between the tonalite of Granite Mountain on the northeast and the Julian Schist of Chariot Mountain on the southwest is exposed immediately west of the boundary between the Julian and Earthquake Valley quadrangles. Coarse, poorly sorted, white- to light-gray-weathering older alluvium $\left(\mathrm{Qoa}_{4}\right)$ overlies, and is probably also cut by, the fault in this area. These alluvial deposits, locally up to $10 \mathrm{~m}$ thick, are horizontally bedded and consist chiefly of clasts of tonalite of Granite Mountain. They range from pebbly sands to cobbles and boulders (up to $2+\mathrm{m}$ ) in a sand matrix. Their texture and composition suggest rapid uplift of Granite Mountain on the northeast side of the Elsinore Fault. The Ranchito Valley-Rodriguez Canyon segment of the Elsinore Fault has also undergone right-lateral slip: the contact between the Harper Creek and Granite Mountain units has been offset right-laterally $\sim 2.5 \mathrm{~km}$ between Banner and the northwest end of Rodriguez Canyon, and a contact between tonalite and the Julian Schist on Chariot Mountain southwest of the fault has been offset right-laterally $\sim 1.3 \mathrm{~km}$, the contact reappearing on the northeast side of the fault in the Earthquake Valley 7.5' quadrangle (M. Grove, oral commun., 1988).

\section{Chariot Canyon Fault}

The Chariot Canyon fault strikes north-northwest to join the Elsinore Fault near the settlement of Banner, where one or more flat gouge zones are exposed in a road cut of State Highway 78. To the south-southeast, the fault continues through the northwest-trending reach of Oriflamme Canyon in the Cuyamaca Peak 7.5' quadrangle into the Laguna Mountains, where it dies out, or is obscured by, a broad zone of high-angle faults (part of the Elsinore Fault Zone; Todd, 1977a). In the northern part of Chariot Canyon, the fault juxtaposes the tonalite of Granite Mountain containing screens of the Julian Schist on the east against a narrow sliver of the gneiss of Harper Creek. In the southern part of the canyon, the fault steps southwest and separates tonalite of Granite Mountain on the east from the Julian Schist on the 
west. It continues southeastward along the foot of a brushy northeast-facing scarp(?) into the northwest reach of Oriflamme Canyon (Cuyamaca Peak quadrangle), where it separates the monzogranite of Pine Valley on the east from the Julian Schist on the west (Todd, 1977a). Fine-grained tonalite dikes of the Granite Mountain unit cut the Pine Valley pluton in Oriflamme Canyon.

The northern part of the Chariot Canyon Fault is localized in a zone of protomylonitic tonalite of Granite Mountain that gives way eastward over a few tens of meters to coarser-grained, weakly to moderately foliated tonalite. This zone apparently represents a protoclastic border of the pluton. Lenticular bodies of strongly foliated to porphyroclastic gabbro lie between the gneiss of Harper Creek and tonalite in the fault zone. Greenschist-facies minerals have replaced magmatic minerals in the mylonitic tonalite and gabbro: chlorite after biotite, actinolite after hornblende, and sericite and albite after plagioclase.

The mylonitic rocks in the Chariot Canyon Fault Zone were overprinted by anastomosing brownish-green cataclastic shears, zones of breccia-gouge as much as several hundred meters wide, and discrete fault planes marked by hard brownish-gray gouge or bluish-black microbreccia, all suggesting a complex history of ductile, ductile-to-brittle, and brittle deformation. The strike of major and minor brittle faults in the zone averages N. $30^{\circ} \mathrm{W}$. and their dips range from $40^{\circ}$ to $90^{\circ}$, averaging $\sim 70^{\circ} \mathrm{NE}$. Striations generally plunge steeply down the dip of fault planes. Donnelly (1934, p. 345-346) described the fault plane in the Golden Chariot mine as "stepped and reverse in type; the fault surface as a whole is curved concave upward and dips under the east wall." Neogene displacement on the Chariot Canyon Fault was probably dip-slip and reverse in sense, with Chariot Mountain uplifted and thrust westward.

The Chariot Canyon Fault hosted gold mineralization at a late stage of batholithic emplacement (Donnelly, 1934; Kofron, 1984). Kofron interpreted the mylonitic zone as having formed during or shortly after intrusion of the tonalite of Granite Mountain. He considered that sericitic alteration of the tonalite and surrounding country rocks occurred at near-magmatic temperatures driven by intrusive heat from regionally extensive late-to-post-tectonic La Posta plutons in the eastern zone of the batholith. At about the same time, metamorphic fluids were produced by dehydration reactions in the country rocks, and ore and gangue minerals were mobilized and deposited in the mylonitic zone. Kofron obtained a cooling age on biotite from mylonitic tonalite of 91.3 $\pm 2.7 \mathrm{Ma}$, indicating that temperatures had dropped to the range $430^{\circ}$ to $230{ }^{\circ} \mathrm{C}$ in the time period since emplacement of the Granite Mountain-Chariot Mountain tonalite pluton at $98 \pm 3 \mathrm{Ma}$. He noted that brittle deformation in the mylonitic zone indicated Neogene reactivation of the Chariot Canyon Fault.

Kofron (1984) considered the Chariot Canyon Fault to be older than the Elsinore Fault because the Late Cretaceous mylonitic tonalite must have formed in a deep-seated environment and subsequently underwent substantial uplift and unroofing. Pinault (1984) noted that the Elsinore Fault truncates the Chariot Canyon Fault and suggested the existence of a right-laterally offset northern extension of the Chariot Canyon Fault (also see Lampe, 1988). At present, this proposed northern extension comprises north-northwest-trending brittle faults in the Harper Creek unit (1) crossing the ridge that forms the east wall of Ranchito Valley, (2) continuing northward beneath the alluvium of Banner Creek, and (3) joining a broad zone of discontinuous north-northwest-trending faults that extends northward across the east flank of Volcan Mountain to the northern boundary of the quadrangle. The Volcan Mountain faults either parallel compositional layering and foliation in the crystalline rocks or cross them at low angles.

The outcrop pattern and apparent structural history of crystalline rocks in the Julian quadrangle make it unlikely that the north-northwest faults crossing the eastern flank of Volcan Mountain represent the offset continuation of the Chariot Canyon Fault. The mylonitic border zone in the Granite Mountain pluton probably formed during and shortly after emplacement of the pluton along that part of its contact with country rocks that was oriented roughly north-northwest. Where the same contact strikes northeast along the western foot of Granite Mountain, there is no mylonitic zone in the tonalite. Neogene faulting was localized in the mylonite zone and probably also along the relatively steep limbs of the northnorthwest-plunging antiform of Chariot Mountain. The Harper Creek rocks on the west side of Chariot 
Canyon may have been tectonically thinned at about the same time. The Neogene fault in Chariot Canyon separates this fold from the gneiss of Harper Creek and the Julian Schist to the west, but the fault's proposed northern extension lies totally within the Harper Creek unit. North-northwest-trending faults on the east side of Volcan Mountain may represent minor accommodations, parallel to foliation in the crystalline rocks, to movements on the Elsinore Fault or related late Cenozoic faults. They may have formed in an extensional setting related to uplift of Volcan Mountain and the San Felipe Hills.

\section{San Felipe Hills Fault Zone}

A small segment of a linear, northwest-trending range known as the San Felipe Hills occupies the northeast corner of the Julian quadrangle. The range is bounded on the southwest by a narrow zone of prominent faults that extends for a minimum of $10 \mathrm{~km}$ from its northwestern end in the Ranchita quadrangle to Earthquake Valley (name changed by real estate developers to Shelter Valley) on the southeast. Only a small part of the San Felipe Hills Fault Zone has been mapped, but the faults in the Julian quadrangle have very youthful topographic expression (scarps, truncated spurs, shutter ridges, notches, right-lateral bending of secondary streams, vegetation stripes) and cut the older alluvial fan on the east side of San Felipe Valley. In the Julian quadrangle, alluvium of the modern fan appears to overlie these faults, but to the north in the Ranchita quadrangle, vegetation lineaments in the youngest alluvial cones suggest recent fault movements.

\section{Displacement on the Elsinore Fault}

In the Julian quadrangle, total slip on the Elsinore Fault was apparently right-oblique with the northeast block(s) up relative to the southwest block. From northwest to southeast, bedrock contacts show right-lateral offsets of approximately $1,2.5$, and $1.3 \mathrm{~km}$. The disparity in these amounts may be due to variable orientations of the offset contacts and (or) variable local amounts of uplift. Recent rightlateral slip is indicated by right-bending of tributary drainages on the northeast side of the fault. The higher elevation of accordant summits on Volcan Mountain relative to the Julian Mesa suggests that the northeast side of the Elsinore Fault has risen on the order of 300 to $400 \mathrm{~m}$ higher than the southwest side. Uplift on Volcan Mountain may have been of greater magnitude to the northwest, as first suggested by Donnelly (1934), because elevations there are greater and because a series of rounded peaks at the northern end of the mountain give way southeastward to somewhat larger, relatively flat erosional remnants at the southern end. The summit of Granite Mountain lies about $300 \mathrm{~m}$ above that of Chariot Mountain. This relation, and the presence of large tonalite boulders in the southeastern part of Rodriguez Canyon, suggest greater uplift of the northeast side of the fault in this area as well.

Neogene faulting apparently was localized in north-northwest to northwest-trending Late Cretaceous structures and contacts. As discussed above, Grove and others (2003) demonstrated a possible 5-km increase in structural depth from west to east across the Chariot Canyon and Oriflamme Canyon Faults, which he attributed to westward-directed ductile thrusting related to the intrusion of large volumes of Late Cretaceous La Posta magma to the east and south. Although the northwestward extent and location of the thrust is unclear, the Banner Canyon segment of the Elsinore Fault apparently follows it because the Julian Schist and the Harper Creek unit on the northeast (Volcan Mountain) side, with their larger proportion of migmatites and paragneiss, apparently formed at significantly greater depths than these same rocks on the southwest side. This thrust, and the Neogene Chariot Canyon Fault, were localized in the western limb of the Late Cretaceous antiform of Chariot Mountain, while the segment of the Elsinore Fault in Ranchito Valley and Rodriguez Canyon apparently followed the east limb of this fold.

Neogene movement on the Elsinore Fault in the Julian quadrangle was part of a complex tectonic regime in the western Colorado Desert that included rifting of the Gulf of California, right slip in the San Andreas Fault Zone, and clockwise rotation of the block between the San Andreas and Elsinore 
Faults (Johnson and others, 1983). At about the same time that the Volcan-Granite Mountain block was rising, the Vallecito-Mason Valley graben was forming (Todd, 1977b; 1978). In some places, Neogene uplift had the same sense of direction as Late Cretaceous uplift, for example, the rise of Volcan and Granite Mountains. In the case of Oriflamme Mountain, the direction of Late Cretaceous vertical motion was apparently reversed during Neogene formation of the Mason Valley graben, because the erosional surface on Oriflamme Mountain appears to have been stepped downward relative to that of the Laguna Mountains. These vertical movements were accompanied by small right-lateral offsets $(1-2 \mathrm{~km})$ in the Campbell Grade area (Todd, 1978).

\section{References Cited}

Berggreen, R.G., and Walawender, M.J., 1977, Petrography and metamorphism of the Morena Reservoir roof pendant, southern California: California Division of Mines and Geology, Special Report 129, p. 61-65.

Bracchi K.A., Girty, G.H., and Girty, M.S., 1993, CLMSZ, Garnet Mountain area, southern CaliforniaA collisionally generated contractional shear zone [abs.]: Geological Society of America Abstracts with Programs, v. 25, no. 5, p. 13.

Bushee, J., Holden, J., Geyer, B., and Gastil, R.G., 1963, Lead-alpha dates for some basement rocks of southwestern California: Geologial Society of America Bulletin, v. 74, p. 803-806.

Creasey, S.C., 1946, Geology and nickel mineralization of the Julian-Cuyamaca area, San Diego County, California: California Journal of Mines and Geology, v. 42, p. 15-29.

Detterman, M.E., 1984, Geology of the Metal Mountain district, In-ko-pah Mountains, San Diego County, California: San Diego, Calif., San Diego State University, M.S. thesis, 216 p.

Donnelly, Maurice, 1934, Geology and mineral deposits of the Julian district, San Diego County, California: California Division of Mines Report 30, p. 331-370.

Everhart, D.L., 1951, Geology of the Cuyamaca Peak quadrangle, San Diego County, California: California Division of Mines Bulletin 159, p. 51-115.

Fairbanks, H.W., 1893, Geology of San Diego; also portions of Orange and San Bernardino Counties: California Minerals Bureau Report 11, p. 76-120.

Foster, B.D., 1994, Origin and tectonic significance of Peninsular Ranges amphibolites: San Diego, Calif., San Diego State University, M.S. thesis, 122 p.

Gastil, R.G., and Miller, R.H., 1984, Prebatholithic paleogeography of peninsula California and adjacent Mexico, in Frizzell, V.A., Jr., ed., Geology of the Baja California Peninsula: Pacific Section, Society of Economic Paleontologists and Mineralogists, v. 39, p. 9-16.

Gastil, G., Girty, G., Wardlaw, M., and Davis, T., 1988, Correlation of Triassic-Jurassic sandstone in peninsular California [abs.]: Geological Society of America Abstracts with Programs, v. 20, no. 3, p. 162.

Germinario, M.P., 1982, The depositional and tectonic environments of the Julian Schist, Julian, California: San Diego, Calif., San Diego State University, M.S. thesis, 95 p.

Germinario, M.P., 1993, The early Mesozoic Julian Schist, Julian, California, in Gastil, R.G., and Miller, R.H., eds., The prebatholithic stratigraphy of Peninsular California: Boulder, Colo., Geological Society of America Special Paper 279, p. 107-118.

Grove, M., 1987, Metamorphism and deformation in the Box Canyon area, eastern Peninsular Ranges, San Diego County, California: Los Angeles, Calif., University of California, M.S. thesis, 174 p. Grove, M., Lovera, O., and Harrison, M., 2003, Late Cretaceous cooling of the east-central Peninsular Ranges batholith $\left(33^{\circ} \mathrm{N}\right)$ - Relationship to La Posta pluton emplacement, Laramide shallow subduction, and forearc sedimentation, in Johnson, S.E., Paterson, S.R., Fletcher, J.M., Girty, G.H., 
Kimbrough, D.L., and Martin-Barajas, A., eds., Tectonic evolution of northwestern Mexico and the southwestern USA: Boulder, Colorado, Geological Society of America Special Paper 374, p. 355-379. Hoggatt, W.C., 1979, Geologic map of the Sweeney Pass quadrangle, San Diego County, California:

U.S. Geological Survey Open-File Report 79-754, 28 p., scale 1:24,000.

Hudson, F.S., 1922, Geology of the Cuyamaca region of California, with special reference to the origin of nickeliferous pyrrhotite: University of California, Bulletin of the Department of Geological Sciences, v. 13, p. 175-252.

Johnson, N.M., Officer, C.B., Opdyke, N.D., Woodard, G.D., Zeitler, P.K., and Lindsay, E.H., 1983, Rates of late Cenozoic tectonism in the Vallecito-Fish Creek basin, western Imperial Valley, California: Geology, v. 11, p. 664-667.

Kennedy, M.P., 1977, Recency and character of faulting along the Elsinore fault zone in southern Riverside County, California: California Division of Mines and Geology Special Report 131, 12 p.

Kofron, R.J., 1984, Age and origin of gold mineralization in the southern portion of the Julian Mining District, southern California: San Diego, Calif., San Diego State University, M.S. thesis, 75 p.

Lampe, C.M., 1988, Geology of the Granite Mountain area-Implications of the extent and style of deformation along the southeast portion of the Elsinore fault: San Diego, Calif., San Diego State University, M.S. thesis, $150 \mathrm{p}$.

Leeson, R.T., Girty, G.H., Wardlaw, M.S., and Meier, D.B., 1989, Harper Creek Gneiss, Peninsular Ranges, southern California [abs.]: Geological Society of America Abstracts with Programs, v. 21, no. 5, p. 105.

Merrill, F.J.H., 1914, Geology and mineral resources of San Diego and Imperial Counties, California: California State Mining Bureau Report 14, p. 653-662.

Nishimori, R.K., 1976, Petrology and geochemistry of gabbros from the Peninsular Ranges and a model for their origin: San Diego, Calif., University of California, Ph.D. dissertation, 272 p.

Pinault, C.T., 1984, Structure, tectonic geomorphology and neotectonics of the Elsinore fault zone between Banner Canyon and the Coyote Mountains, southern California: San Diego, Calif., San Diego State University, M.S. thesis, 231 p.

Shaw, S.E., Todd, V.R., and Grove, M., 2003, Jurassic peraluminous gneissic granites in the axial zone of the Peninsular Ranges, southern California, in Johnson, S.E., Paterson, S.R., Fletcher, J.M., Girty, G.H., Kimbrough, D. L., and Martin-Barajas, A., eds., Tectonic evolution of northwestern Mexico and the southwestern USA: Boulder, Colo., Geological Society of America Special Paper 374, p. 157-183.

Streckeisen, A.L., 1973, Plutonic rocks, classification and nomenclature recommended by the I.U.G.S. Subcommission on the Systematics of Igneous Rocks: Geotimes, v. 18, no. 10, p. 26-30.

Thomson, C.N., and Girty, G.H., 1994, Early Cretaceous intra-arc ductile strain in Triassic-Jurassic and Cretaceous continental margin arc rocks, Peninsular Ranges, California: Tectonics, v. 13, p. 11081119.

Todd, V.R., 1977a, Geologic map of the Cuyamaca Peak quadrangle, San Diego County, California: U.S. Geological Survey Open-File Report 77-405, 13 p., 1 sheet, scale 1:24,000.

Todd, V.R., 1977b, Geologic map of the Agua Caliente Springs, quadrangle, San Diego County, California: U.S. Geological Survey Open-File Report 77-742, 20 p., 1 sheet, scale 1:24,000.

Todd, V.R., 1978, Geologic map of the Monument Peak quadrangle, San Diego County, California: U.S. Geological Survey Open-File Report 78-697, 47 p., 1 sheet, scale 1:24,000.

Todd, V.R., 1979, Geologic map of the Mount Laguna quadrangle, San Diego County, California: U.S. Geological Survey Open-File Report 79-862, 39 p., 1 sheet, scale 1:24,000.

Todd, V.R., 2004, Preliminary geologic map of the El Cajon 30`x 60' quadrangle, southern California: U.S. Geological Survey Open-File Report 2004-1361, 1 sheet, scale 1:100,000.

Todd, V.R., and Shaw, S.E., 1979, Structural, metamorphic and intrusive framework of the Peninsular Ranges batholith in southern San Diego County, California, in Abbott, P.L., and Todd, V.R., eds., 
Mesozoic Crystalline Rocks: San Diego, Calif., San Diego State University, Department of Geological Sciences, Guidebook for Geological Society of America Annual Meeting., 1979, p. 177-231.

Todd, V.R., Erskine, B.G., and Morton, D.M., 1988, Metamorphic and tectonic evolution of the northern Peninsular Ranges batholith, southern California, in Ernst, W.G., ed., Metamorphism and Crustal evolution of the western United States: New Jersey, Prentice-Hall, Rubey volume VII, p. 894-937.

Todd, V.R., Shaw, S.E., and Hammarstrom, J.H., 2003, Cretaceous plutons of the Peninsular Ranges batholith, San Diego and westernmost Imperial Counties, California-Intrusion across a Late Jurassic continental margin, in Johnson, S.E., Paterson, S.R., Fletcher, J.M., Girty, G.H., Kimbrough, D.L., and Martin-Barajas, A., eds., Tectonic evolution of northwestern Mexico and the southwestern USA: Boulder, Colo., Geological Society of America Special Paper 374, p. 185-235.

Weber, F.H., Jr., 1963, Geology and mineral resources of San Diego County: California Division of Mines and Geology, County Report 3, 309 p.

Woodard, G.D., 1974, Redefinition of Cenozoic stratigraphic column in Split Mountain Gorge, Imperial Valley, California: American Association of Petroleum Geologists Bulletin, v. 58, p. 521-526. 